\title{
ДИСТАНЦІЙНЕ НАВЧАННЯ СТУДЕНТІВ-ЗАОЧНИКІВ ФАРМАЦЕВТИЧНОГО ФАКУЛЬТЕТУ В МЕДИЧНОМУ ВНЗ
}

\author{
Л. М. Унгурян, Г. В. Чернецька, І. А. Науменко \\ Одеський національниймедичний університет
}

\author{
DISTANCE EDUCATION OF EXTERNAL STUDENTS OF \\ PHARMACEUTICAL FACULTY IN HIGHER MEDICAL SCHOOL
}

\author{
L. M. Unhuryan, H. V. Chernetska, I. A. Naumenko \\ Odesa National Medical University
}

\begin{abstract}
У цій статті розглядаються можливості впровадження дистанційних технологій у навчальний процес студентів-заочників. В даний час зростає кількість інформації, яка так необхідна для отримання, розуміння і засвосння знань. На сучасному етапі розвитку освіти стала актульною проблема пошуку нових форм організації навчального процесу. Це спричинило впровадження інформаційних технологій в освіту і формування окремого виду навчання - дистанційного. Дистанційне навчання можна розглядати як найважливіший чинник економічного зростання та соціального розвитку.
\end{abstract}

This article focuses on the learning process and the possibility of the introduction of distance technologies in the educational process. There is an increasing amount of information that is so necessary for obtaining, understanding and assimilation of educational levels. At the stage of development of education a real problem for finding new forms of school organization becomes urgent. This entailed the introduction of information technology in education and the formation of a particular type of education - distance learning. Distance learning can be regarded as the most important factor of economic growth and social development.

Вступ. Людство вступило в новий етап свого розвитку, коли інформаційні процеси стають однією 3 найважливіших складових життєдіяльності людини, тому на етапі розвитку освіти стала актуальною проблема пошуку нових форм організації навчального процесу. Сучасна система вищої освіти переживає великі зміни, що приводять до вдосконалення і появи нових освітніх технологій. Сьогоднішні вищі навчальні заклади повинні активно позиціонувати свій внесок в інноваційний процес, соціальний розвиток і розробляти інноваційні технології, які забезпечать формування професійних умінь у студентів. В даний час зростає кількість інформації, яка так необхідна для отримання, розуміння і засвоєння рівнів освіти. Це спричинило впровадження інформаційних технологій в освіту і формування окремого виду навчання - дистанційного. Дистанційне навчання - цепринципово новий, високотехнологічний підхід до процесу передачі знань.

Основна частина. Система дистанційного навчання використовується у всіх країнах та відіграє все більш значущу роль. Сьогодні заочно можна отримати вищу освіту, вивчити іноземну мову, підготуватися до вступу у ВНЗ і так далі. Дистанційне навчання $є$ доступним засобом отримання освіти для широкого кола людей без відриву від основної діяльності. Дистанційне навчання - цепринципово новий, високотехнологічний підхід до процесу передачі знань.

Tермін distant education (дистанційне навчання) вперше був використаний у каталозі заочних кореспондентських курсів Університету штату Вісконсін в 1892 році. У 1939 році був заснований Французький національний центр дистанційного навчання (CNED). Національний університет дистанційної освіти (UNED) в Іспанії і Балтійський університет (BU) зі штаб-квартирою в Стокгольмі об'єднує 10 країн Балтійського регіону. У Канаді в 1972 р. з'являється Відкритий університет, у якому в даний час понад 14000 студентів навчаються бізнесу, мистецтва, інформаційних технологій. У 1974 році в Німеччині створений Ферн (Хаген) - університет з програмами навчання з гуманітарних, соціальних, економічних та комп'ютерних наук. Число студентів - 55 000. У 1993 році в США відкрився міжнародний університет бізнесу, де навчаються 30000 студентів з використанням дистанційних освітніх технологій. Одним 3 найбільш авторитетних у сфері дистанційної освіти сьогодні визнається Пенсільванський університет (Penn State University). Дистанційні освітні бізнес-

( Л. М. Унгурян, Г. В. Чернецька, І. А. Науменко 
програми складають 25 \% всіх дистанційних освітніх програм в Америці. У ряді країн (Китай, Латвія, Нідерланди, Алжир, Великобританія, Туреччина та iн.) від 10 до $25 \%$ студентів здобуває освіту в установах дистанційного навчання.

Дистанційне навчання - дуже гнучка система, вона дозволяє всім учасникам навчального процесу (студентам, викладачам і адміністраторам навчального закладу) обирати зручний час занять. Ця система дозволяє набути необхідних навичок і нових знань за допомогою персонального комп'ютера (ПК) і виходу в мережу Інтернет. Місце розташування ПК не має значення, тому вчитися можна вдома, на роботі, а також в будь-якому іншому місці, де $\epsilon$ ПК з доступом до мережі Інтернет.

При використанні технологій дистанційного навчання кожний студент може отримати потрібну освіту без необхідності очної присутності у ВНЗ. Це хороше вирішення питання для тих, хто хоче поєднувати роботу $з$ навчанням, зайнятий вихованням малюка або за станом здоров' я не може покинути місце проживання. Особиста присутність студента в навчальному закладі потрібна тільки для підсумкових контрольних занять.

Принциповою відмінністю дистанційного навчання від традиційних видів є те, що в його основі лежить самостійна пізнавальна діяльність студента. Важливо, щоб студент не тільки опанував певними знаннями, але і навчився самостійно їх здобувати, працював з інформацією, оволодів способами пізнавальної діяльності, які в подальшому міг би застосовувати в умовах безперервної самоосвіти.

Досвід викладання на фармацевтичному факультеті дозволяє зробити висновок про те, що найважливішою умовою підвищення ефективності навчання є психологічна, теоретична і практична готовність студентів до самостійної роботи. Самостійне оволодіння знаннями не повинно носити пасивний характер, навпаки, студент із самого початку повинен бути залучений в активну пізнавальну діяльність, яка не обмежується оволодінням знаннями, але неодмінно передбачає їх застосування для вирішення різноманітних проблем у своій практичній діяльності. В ході такого навчання студенти повинні навчитися здобувати і застосовувати знання, шукати і знаходити потрібні для них засоби навчання та джерела інформації, уміти працювати з цією інформацією.

Сучасне оснащення вищих навчальних закладів матеріально-технічними засобами дозволяє прискорити цей освітній процес. Досягти цього дозволяють інформаційні технології, такі, як: обмін інформацією між учасниками навчального процесу за допомогою мережі Інтернет (розсилка навчальної літератури, рішення практичних і самостійних завдань та ін., вивчення теоретичних аспектів дисциплін, що вивчаються). Студенти через Інтернет мають доступ до електронної бібліотеки університету. Навчальний матеріал повинен бути доступний студенту, по можливості, в декількох видах, наприклад: по Internet, на CD-диску, в друкованому вигляді.

Введення дистанційного навчання вимагає створення та постійного оновлення навчально-методичної бази, створення мультимедійних та мережевих курсів з дисциплін, планомірного підвищення кваліфікації викладачів і навчально-методичного персоналу. Необхідний перегляд сучасної методики навчання, моделі взаємодії викладачів і студентів.

Характерними рисами дистанційної освіти є:

- гнучкість: студенти не відвідують регулярних занять у вигляді лекцій і семінарів, а працюють у зручний для себе час у зручному місці;

- модульність: в основу дистанційної освіти кладеться модульний принцип. Кожний окремий курс створює цілісне уявлення про певну галузь знань;

- економічна ефективність: досвід вітчизняних недержавних центрів показує, що їх витрати складають приблизно $60 \%$ витрат на підготовку фахівців за денною формою;

- нова роль викладача: на нього покладаються такі функції, як координування пізнавального процесу, коректування курсу, що викладається, консультування при складанні індивідуального навчального плану та ін.;

- спеціалізовані форми контролю: в якості форм контролю використовуються дистанційно організовані співбесіди, практичні і курсові роботи;

- використання спеціалізованих технологій: технологія дистанційної освіти - це сукупність методів, форм і засобів взаємодії в процесі самостійного, але контрольованого освоєння певного об' єму знань.

Дистанційну форму навчання можна застосовувати і при підвищенні кваліфікації викладачів. Розвиток дистанційного навчання дозволить збільшити кількість студентів-заочників, використання широкого спектра сучасних освітніх технологій, підвищення якості освіти.

Особливо ефективним є застосування дистанційного навчання для студентів заочного навчання, де в порівнянні з денним відділенням збережено необхідний обсяг матеріалу, що вивчається, а кількість навчальних годин скорочено. Дистанційна освіта забезпечує, з одного боку, ефективний оперативний зворотний зв'язок, закладений в самому навчально- 
му матеріалі, а 3 іншого - безпосередній систематичний зворотний зв' язок з викладачем по мережі, а також можливість спілкування в мережі з партнерами. При цьому передбачається активна участь у діалозі обох сторін - обмін питаннями і відповідями, управління ходом діалогу, контроль за виконанням завдань та ін. В цілому в структуру матеріалу включаються такі змістовні компоненти: власне навчальний матеріал, включаючи необхідні ілюстрації; інструкції по його освоєнню; питання і тренувальні завдання; контрольні завдання та пояснення до їх виконання. Забезпечення зворотного зв' язку між студентами і викладачем дозволяє здійснювати постійний контроль за діяльністю студентів, проблемами, які у них виникають. Механізм зворотного зв' язку націлений на перевірку виконання цілей і завдань по кожному етапу навчання. Зворотний зв' язок може здійснюватися в будь-якій формі, в тому числі і у вигляді контрольного тестування (початкового, проміжного, заключного), дискусій, телеконференцій. Для цього можна використовувати різні анкети і тести, для відповідей на які студенту достатньо вписати в потрібному рядку форми відповідь або вибрати правильну відповідь 3 декількох запропонованих варіантів, а потім відправити електронною поштою.

У процесі дистанційного навчання дуже важливо організувати оперативну відповідь викладачів на запитання студентів. Комп'ютерні телекомунікації створюють для цього всі необхідні умови, забезпечуючи оперативну передачу інформації по електронній пошті або організовуючи консультації в рамках телеконференції. Сучасні інформаційні технології надають практично необмежені можливості в розміщенні, зберіганні, обробці та доставці інформації на будь-які відстані і будь-якого обсягу і змісту.

Висновки. Дистанційне навчання вельми зручне і корисне, це крок в освіту майбутнього. Але всетаки не варто забувати про традиційну освіту, яка дає більше навичок, особливо при отриманні основної освіти. Дистанційне навчання поки рекомендується отримувати як додаткове. Воно $є$ найефективнішою системою підготовки і безперервного підтримання високого кваліфікаційного рівня фахівців. Тому однією 3 найважливіших характеристик інноваційного вузу $є$ розвиток дистанційної освіти. Процес дистанційної освіти можна охарактеризувати як: гнучке поєднання самостійної пізнавальної діяльності студентів 3 різними джерелами інформації, навчальними матеріалами, спеціально розробленими по даному курсу; оперативна і систематична взаємодія 3 провідним викладачем курсу; групову роботу за типом навчання в співробітництві з учасниками даного курсу; обмін думками, інформацією з учасниками курсів, а також з будь-якими іншими партнерами, в тому числі і закордонними за допомогою Internet. Таким чином, дистанційне навчання, як одна 3 форм отримання освіти, може допомогти вирішити завдання, що стоять перед системою освіти 3 наданням широким верствам населення доступної і якісної освіти в сучасних соціально-економічних умовах.

сування. Дистанційний курс : навчальний посібник / В. М. Кухаренко, О. В. Рибалко, Н. Г. Сиротенко; за ред. В. М. Кухаренка. - [3-те вид.]. - Харків : НТУ "ХПІ", "Торсінг", 2002. - 320 c.

5. Интернет-обучение: технологии педагогического дизайна / М. В. Моисеева, Е. С. Полат, М. Ю. Бухаркина, М. И. Нежурина; под ред. М. В. Моисеевой. - М. : Издательский дом “Камерон”, 2004. 